\title{
BERAS KETAN HITAM SEBAGAI AGEN TERAPI PADA PASIEN PENDERITA DIABETES MELLITUS DI DESA SOBAYAN KECAMATAN PEDAN KABUPATEN KLATEN
}

\author{
Devina Ingrid Anggraini ${ }^{1 *}$, Atur Semartini ${ }^{2}$, Vita Anggun Cahyani ${ }^{3}$ \\ ${ }^{1}$ Prodi D3 Farmasi, Sekolah Tinggi Ilmu Kesehatan Nasional \\ Jl. Yos Sudarso 338 Surakarta 57155, Jawa Tengah \\ ${ }^{2}$ Prodi D3 Farmasi, Sekolah Tinggi Ilmu Kesehatan Nasional \\ Jl. Yos Sudarso 338 Surakarta 57155, Jawa Tengah \\ ${ }^{3}$ Prodi D4 Fisioterapi, Sekolah Tinggi Ilmu Kesehatan Nasional \\ J1. Yos Sudarso 338 Surakarta 57155, Jawa Tengah \\ *Email: devina.ia@gmail.com
}

\begin{abstract}
Abstrak
Penyakit diabetes mellitus merupakan penyebab kematian tertinggi ketiga di Indonesia. Prevalensi orang dengan diabetes mellitus di Indonesia menunjukkan kecenderungan meningkat yaitu dari 5,7\% pada tahun 2007 menjadi 6,9\% pada tahun 2018. Hal tersebut mendorong untuk perlunya dilakukan sosialisasi kepada masyarakat guna menerapkan pola hidup sehat baik dari sisi olahraga maupun makanan yang dikonsumsi. Tujuan dari kegiatan pengenalan beras ketan hitam sebagai agen terapi pada penderita diabetes mellitus ini adalah untuk memberikan pengetahuan kepada warga masyarakat tentang penggunaan bahan alami sebagai bahan pengendali kadar gula dalam darah. Kegiatan ini dilaksanakan secara rutin dalam Program Pengelolaan Penyakit Kronis (Prolanis) di wilayah Desa Sobayan, Kecamatan Pedan, Kabupaten Klaten dengan peserta adalah pasien penderita diabetes mellitus yang tergabung dalam sebuah wadah bernama Klub Prolanis Dadi Waras. Rangkaian kegiatan meliputi penimbangan berat badan, mengukur tekanan darah pasien, senam prolanis, penyuluhan mengenai terapi bagi penderita diabetes, workshop pembuatan seduhan beras ketan hitam, serta pengambilan darah guna memantau kadar gula dalam darah dari bulan ke bulan. Evaluasi dilakukan dengan membandingkan kadar gula pasien sebelum dan sesudah adanya edukasi mengenai terapi bagi penderita diabetes.
\end{abstract}

KATA KUNCI: Diabetes mellitus, prolanis, beras ketan hitam

\section{PENDAHULUAN}

Diabetes mellitus adalah penyakit gangguan metabolik terutama metabolisme karbohidrat yang disebabkan oleh berkurangnya atau ketiadaan hormon insulin dari sel beta pankreas, atau akibat gangguan fungsi insulin, atau keduanya (Sutedjo, 2010). Diabetes mellitus adalah suatu kumpulan gejala yang timbul pada seseorang disebabkan oleh adanya peningkatan kadar gula glukosa darah akibat kekurangan insulin baik absolut maupun relatif (Syahbudin, 2009). Menurut WHO tahun 2011, diabetes mellitus termasuk penyakit yang paling banyak diderita oleh penduduk di seluruh dunia dan merupakan urutan keempat dari prioritas penelitian nasional untuk penyakit degeneratif (ADA,2011). Prevalensi Diabetes Mellitus pada populasi dewasa di seluruh dunia diperkirakan akan meningkat sebesar 35\% dalam dua dasawarsa dan menjangkit 300 juta orang dewasa pada tahun 2025. Bagian terbesar peningkatan angka pravalensi ini akan terjadi di negara-negara berkembang (Gibney, 2009).

Bahan alam yang mempunyai khasiat antidiabetes salah satunya adalah beras ketan hitam. Beras ketan hitam merupakan salah satu jenis beras yang mengandung senyawa metabolit sekunder seperti : alkaloid, flavonoid, tannin, dan steroid (Adrianta, 2016). Beras ketan hitam mempunyai efek menguntungkan bagi tubuh seperti perlindungan terhadap penyakit kardiovaskuler, diabetes mellitus, antiinflammasi, antikanker dan antioksidan. Flavonoid dalam beras ketan hitam ini dapat digunakan untuk menurunkan kadar glukosa darah, yaitu dengan 
menghambat kerja enzim $\alpha$-glukokinase yang terdapat di usus halus (Brahmachari, 2011). Enzim $\alpha$-glukokinase berfungsi untuk menghidrolisis oligosakarida menjadi monosakarida yang terdapat pada dinding usus halus. Penghambatan kerja enzim ini secara efektif dapat mengurangi pencernaan karbohidrat dalam bentuk molekul besar seperti polisakarida dan oligosakarida menjadi molekul yang lebih sederhana seperti glukosa, sehingga absorbsi glukosa dapat dikurangi (Ratimanjari. 2011).

Salah satu penelitian melaporkan bahwa ekstrak etanol beras ketan hitam memiliki aktivitas dalam penurunan kadar glukosa darah $(\rho<0.01)$ dengan dosis efektif $195 \mathrm{mg} / \mathrm{kg} \mathrm{BB}$ yang bila dibandingkan dengan Glibenklamid diperoleh nilai $\rho>0.05$ dalam menurunkan kadar glukosa darah (Suasana, 2016). Ekstrak V.amygdalina dan Beras Ketan hitam (O. sativa glutinosa) pada beberapa variasi dosis juga dibuktikan mampu menurunkan kadar gula darah mencit yang telah diinduksi aloksan (Sarofah, 2016). Iryani (2017) menyimpulkan bahwa ekstrak berair dari beras ketan hitam dapat menurunkan kadar glukosa darah, dan penurunan tertinggi terjadi pada dosis $500 \mathrm{mg} / \mathrm{kg} \mathrm{BB}$.

Tujuan pengabdian kepada masyarakat ini adalah dapat meningkatkan pengetahuan dan ketrampilan warga masyarakat tentang pentingnya pemanfaatan tanaman obat tradisional khususnya didaerah sekitar untuk pengobatan hipertensi.

\section{METODE}

Sasaran dari pengabdian ini adalah pasien penderita diabetes mellitus yang tergabung dalam Klub Prolanis Dadi Waras dan terdaftar sebagai anggota BPJS dengan fasilitas kesehatan tingkat 1 sama. Bentuk kegiatan pengabdian yaitu melalui penimbangan berat badan pasien, cek tekanan darah, senam prolanis, penyuluhan dan workshop tentang Beras Ketan Hitam Sebagai Agen Terapi Pada Penderita Diabetes Mellitus, serta cek kadar gula darah. Urutan acara pelaksanaan meliputi registrasi peserta, pengecekan berat badan dan tekanan darah pasien, senam prolanis, pemberian leaflet tentang terapi diabetes mellitus, dilanjutkan acara penyuluhan dan workshop pembuatan seduhan beras ketan hitam, serta pengambilan darah guna mengetahui kadar gula dalam darah pasien.

\section{HASIL DAN PEMBAHASAN}

Pengabdian kepada masyarakat adalah bentuk tanggung jawab sosial atas pengembangan dan penguasaan ilmu pengetahuan, teknologi, dan seni suatu institusi, langsung kepada masyarakat secara melembaga melalui metode ilmiah yang berorientasi pada pemecahan masalah. Tujuan kegiatan tersebut adalah mempercepat proses penguasaan ilmu sesuai tuntutan dinamika pembangunan yang merupakan aplikasi dari konsep pendidikan seumur hidup. Acara pengabdian masyarakat yang dilaksanakan dengan berbagai rangkaian kegiatan seperti penimbangan berat badan, cek tekanan darah, senam prolanis, penyuluhan tentang beras ketan hitam sebagai agen terapi bagi penderita diabetes mellitus, workshop membuat seduhan ketan hitam yang praktis dan mudah diaplikasikan dalam kehidupan sehari-hari, serta pengambilan darah guna mengetahui kadar gula darah dari pasien penderita diabetes mellitus.

Kegiatan yang dilakukan dengan registrasi peserta Klub Prolanis Dadi Waras terlebih dahulu. Data peserta yang dicatat pada saat registrasi yaitu nama, umur, alamat, nomor telepon, berat badan, tekanan darah, dan diakhiri dengan tanda tangan sebagai bukti hadir peserta. Setelah melakukan registrasi peserta dipersilahkan untuk bersiap mengikuti senam prolanis yang dipandu oleh instruktur. Senam berlangsung selama kurang lebih 1 jam dengan urutan pemanasan, senam inti dengan metode low impact, dan pendinginan. Tujuan dilaksanakan senam prolanis ini adalah guna melancarkan peredaran darah, karena rata-rata pasien diabetes mellitus yang tergabung dalam Klub Prolanis Dadi Waras adalah bapak ibu dengan usia lanjut ( $>45$ tahun), sehingga aktivitas tubuh yang dilakukan sehari-hari relatif kurang. Setelah senam selesai, peserta dipersilahkan untuk duduk dan dibagikan leaflet beras ketan hitam sebagai alternatif terapi bagi penderita diabetes mellitus. Kegiatan penyuluhan dan workshop dilakukan dengan metode ceramah dan dilanjutkan dengan sesi diskusi, dimana antusias dari peserta cukup tinggi. Hal tersebut terlihat dari cukup banyaknya pertanyaan untuk mengaplikasikan beras ketan hitam ini dalam kehidupan sehari-hari sehingga kadar gula dalam darah akan terjaga dalam kondisi normal. Kegiatan 
selanjutnya adalah pengambilan darah untuk mengetahui kadar gula darah pasien diabetes mellitus dan nantinya akan dievaluasi dalam kegiatan prolanis bulan berikutnya.

Berdasarkan pengamatan pada sesi tanya jawab, masyarakat memberikan tanggapan positif dan antusiasme. Dari hasil survei diperoleh hasil persentase sebesar $54,16 \%$ dari 30 peserta merasa bahwa kegiatan pengabdian masyarakat yang dilaksanakan sangat menarik untuk diikuti.

\title{
Tabel 1. Hasil survey
}

\author{
Tingkat ketertarikan \\ Sangat menarik \\ Menarik \\ Cukup menarik \\ Kurang menarik \\ Tidak menarik
}

Persentase
$54,17 \%$
$29,16 \%$
$16,67 \%$
$0,0 \%$
$0,0 \%$

Pada tabel 2 menunjukkan bahwa setelah 1 bulan diadakannya penyuluhan menunjukkan bahwa kadar gula darah pasien diabetes mellitus setelah puasa 10 jam yang dapat terjaga $<126 \mathrm{mg} / \mathrm{dL}$ sebanyak sebanyak 40,00\% menjadi 63,33\%, dalam kondisi tinggi yaitu antara $126-200 \mathrm{mg} / \mathrm{dL}$ sebanyak 30,00\% menjadi 23,33\%, sedangkan dalam kondisi cukup tinggi >200 mg/dl sebanyak 30,00\% menjadi 13,34\%. Kesimpulan tersebut didapatkan dari data hasil pengukuran gula darah setelah puasa 10 jam yang dilakukan saat penyuluhan dan 1 bulan setelah penyuluhan. Berdasarkan data tersebut terlihat bahwa setelah aplikasi seduhan beras ketan hitam dalam kehidupan sehari-hari dan menjaga pola makan serta menjauhi makanan yang banyak mengandung gula, maka sebagian besar pasien penderita diabetes mellitus dapat menjaga kadar gula darah setelah puasa 10 jam dalam kondisi normal yaitu $<126 \mathrm{mg} / \mathrm{dL}$. Penyuluhan maupun workshop yang dilakukan dikatakan berhasil karena telah dapat menurunkan persentase penderita diabetes mellitus yang memiliki kadar gula darah diatas ambang normal dan memberikan pengetahuan kepada masyarakat tentang alternatif terapi bagi penderita diabetes mellitus.

Tabel 2. Hasil pengecekan kadar gula dalam darah

\begin{tabular}{|c|c|c|c|}
\hline $\begin{array}{c}\text { Parameter Kadar Gula } \\
\text { Darah Puasa }\end{array}$ & Keterangan & $\begin{array}{c}\text { Persentase saat } \\
\text { penyuluhan }\end{array}$ & $\begin{array}{c}\text { Persentase } \\
\text { setelah } \\
\text { penyuluhan }\end{array}$ \\
\hline$<126 \mathrm{mg} / \mathrm{dl}$ & Normal & $40,00 \%$ & $63,33 \%$ \\
\hline $127-200 \mathrm{mg} / \mathrm{dl}$ & Tinggi & $30,00 \%$ & $23,33 \%$ \\
\hline$>200 \mathrm{mg} / \mathrm{dl}$ & Sangat tinggi & $30,00 \%$ & $13,34 \%$ \\
\hline
\end{tabular}

Pelaksanaan workshop pembuatan seduhan beras ketan hitam dilakukan berdasarkan survei lapangan dimana bahan tersebut mudah didapatkan namun belum dimanfaatkan masyarakat karena kurangnya pengetahuan. Manfaat dari pembuatan seduhan beras ketan hitam ini adalah dapat menjaga kadar gula darah pada pasien penderita diabetes mellitus dengan mengkonsumsinya 2 kali dalam seminggu dan menurunkan kadar gula darah jika dikonsumsi rutin sehari 3 kali. Pelaksanaan pengabdian masyarakat ini diharapkan bisa menjadi wadah berbagi ilmu khususnya bagi pasien penderita diabetes mellitus dan juga dapat mengaplikasikan sentuhan teoritis ke dalam masyarakat.

\section{KESIMPULAN DAN SARAN}

\section{Kesimpulan}

Kesimpulan dari kegiatan pengabdian masyarakat yang dilaksanakan di Desa Sobayan Kecamatan Pedan Kabupaten Klaten ini adalah dengan mengaplikasikan seduhan beras ketan hitam dalam kehidupan sehari-hari khususnya bagi pasien penderita diabetes mellitus yang tergabung di Klub Prolanis Dadi 
Waras, maka kadar gula darah pasien setelah 10 jam puasa dapat terjaga dalam keadaan normal dan juga mampu menurunkan kadar gula darah yang masih melebihi ambang batasnya.

\section{Saran}

Saran untuk kegiatan pengabdian ini adalah diupayakan memberikan wawasan keilmuan, manfaat, dan aplikasi bahan alam yang lain sehingga alternatif terapi bagi penderita diabetes mellitus lebih beragam.

\section{DAFTAR PUSTAKA}

ADA (American Diabetes Assosiation) . 2011. Diagnosis And Classification Of Diabetes Mellitus. Diabetes Care. 34. (1) : 42-57.

Adrianta, Ketut Agus. 2016. Identifikasi Senyawa Antosianin dan Metabolit Sekunder dari Ekstrak Etanol Beras Ketan Hitam (Oryza sativa L.) dalam Pemanfaatannya sebagai Alternatif Pengobatan Demam Berdarah Dengue. Medicamento. 2 : 17-22.

Brahmachari, G. 2011. Bio-Flavonoids with Promising Antidiabetic Potentials: A Critical Survey. Research Signpost : 187-212.

Gibney, M.J. 2009. Gizi Kesehatan Masyarakat. Jakarta: EGC.

Iryani, Iswendi, dan Katrina, I. T. 2017. Uji Aktivitas Antidiabetes Mellitus Senyawa Metabolit Sekunder Fraksi Air dari Beras Ketan Hitam (Oryza sativa L. glutinosa) Pada Mencit Putih. Eksakta. 18. (1) : 1-7

Ratimanjari, D. A. 2011. Pengaruh Pemberian Infusa Herba Sambiloto (Andrographis paniculata Nees) Terhadap Glibenklamid dalam Menurunkan Kadar Glukosa Darah Tikus Putih Jantan Yang Dibuat Diabetes. Skripsi. Depok : Fakultas Matematika dan Ilmu Pengetahuan Alam Program Studi Farmasi Universitas Indonesia.

Sarofah, Umi, Sudrajat dan Nova Hariani. 2016. Pengaruh Ekstrak Daun Vernonia amygdalina Delile dan Beras Ketan Hitam (Oryza sativa glutinosa) Terhadap Penurunan Kadar Gula Darah Mencit (Mus musculus) Yang diinduksi Aloksan. Prosiding Seminar Sains dan Teknologi FMIPA Unmul. Samarinda : FMIPA Unmul

Suasana, D., Ayu, W. D., dan Ibrahim, A. 2016. Aktivitas Ekstrak Etanol Beras Ketan Hitam (Oryza sativa L. glutinosa) Terhadap Penurunan Kadar Glukosa darah Mencit (Mus Mmusculus). Prosiding Seminar Nasional Tumbuhan Obat Indonesia Ke-50. Samarinda : Fakultas Farmasi Universitas Mulawarman.

Sutedjo, A. Y. 2010. 5 Strategi Penderita Diabetes Mellitus Berusia Panjang. Yogjakarta : Kanisius.

Syahbudin, S. 2009. Diabetes Melitus dan Pengelolaannya. Cetakan 2, Pusat Diabetes \& Lipid RSUP Nasional Dr. Cipto Mangunkusumo. Jakarta: FKUI. 